\author{
UNIVERSIDADE DE SÃO PAULO \\ FACULDADE DE ODONTOLOGIA DE BAURU
}

BIANCA TOZI PORTALUPPE BERGANTIN

Performance of giomer-based resin composites under erosive wear and its influence on the adjacent enamel alteration: in vitro study

Desempenho de resinas compostas a base de giomer submetidas ao desgaste erosivo e sua influência na alteração do esmalte adjacente: estudo in vitro

BAURU 

Performance of giomer-based resin composites under erosive wear and its influence on the adjacent enamel alteration: in vitro study

Desempenho de resinas compostas a base de giomer submetidas ao desgaste erosivo e sua influência na alteração do esmalte adjacente: estudo in vitro

Dissertação apresentada a Faculdade de Odontologia de Bauru da Universidade de São Paulo para obtenção do título de Mestre em Ciências no Programa de Ciências Odontológicas Aplicadas, na área de concentração Odontopediatria.

Orientadora: Profa. Dra. Daniela Rios Honório

\section{Versão Corrigida}




\section{Bergantin, Bianca Tozi Portaluppe}

Performance of giomer-based resin composites under erosive wear and its influence on the adjacent enamel alteration: in vitro study / Bianca Tozi Portaluppe Bergantin. - Bauru, 2019.

$$
51 \text { p.: il. ; } 31 \mathrm{~cm} \text {. }
$$

Dissertação (Mestrado) - Faculdade de Odontologia de Bauru. Universidade de São Paulo

Orientadora: Profa. Dra. Daniela Rios Honório

Nota: A versão original desta dissertação encontra-se disponível no Serviço de Biblioteca e Documentação da Faculdade de Odontologia de Bauru - FOB/USP.

Autorizo, exclusivamente para fins acadêmicos e científicos, a reprodução total ou parcial desta dissertação, por processos fotocopiadores e outros meios eletrônicos.

Assinatura:

Data: 
FOLHA DE APROVAÇÃO 



\section{DEDICATÓRIA}

Dedico este trabalho a Deus e a minha família, os quais cederam luz para percorrer este caminho, me deram fé para confiar na certeza da perfeição divina, proveram todo tipo de apoio necessário e amor para cumprir este desafio. 



\section{AGRADECIMENTOS}

A Deus, que é a certeza, a perfeição e a vida, quem me abriu caminhos e me manteve forte para chegar onde estou. Obrigada meu Pai!

Aos meus pais, Lilian Cristiane Tozi Bergantin e Carlos Eduardo Portaluppe Bergantin, pelo amor, dedicação e esforço para minha formação, educação e caráter. Por estarem sempre ao meu lado, me apoiando, me ouvindo e me guiando, por cada ensinamento e palavra de conforto e de crescimento. Antes de ser para mim, este trabalho é para vocês, minha inspiração, meu espelho! Amo vocês incondicionalmente!

Ao meu irmão Bruno Tozi Portaluppe Bergantin, por me aconselhar e me aguentar quando eu mostrava os piores lados da minha personalidade, desde sempre sendo o humor que colava qualquer situação. Obrigada, amo você!

A minha Vó Neyde Portaluppe Bergantin, por cada oração, palavra de conforto e por acreditar tanto em mim! Muito ainda está por vir! Obrigada por estar ao nosso lado sempre! Amo a senhora!

Ao meu namorado e parceiro Kim Tanabe de Moura Leite, por revirar minha vida quando tudo estava desabando, me devolver motivação e me lembrar de quem eu sou em todos os momentos. Por toda a ajuda durante cada etapa do mestrado, cada ideia e dedicação em sempre me fazer sorrir! Por ser tão você, me faz querer ser mais eu! Te amo infinito!

A minha orientadora Pra. Dra. Daniela Rios Honório, pela confiança e oportunidades, por todo ensinamento e crescimento. Obrigada pela dedicação na minha formação, aprendi muito sobre Odontologia, Pesquisa e sobre a vida!

As minhas amigas da vida, Beatriz Lima Netto (Mana), Isabela Mesquita (Crô), Thais Figueiredo e minha cunhada Nicole Costa, por toda risada, gargalhada e choro juntas comigo, me animando em momentos difíceis e aproveitando momentos gostosos! Amo vocês! 

A minha colega de Mestrado Camilla Cristina Lira Di Leoni, por toda ajuda, paciência e descontração, por me doar tanto do seu tempo e esforço para que tudo desse certo! Muito obrigada Ca!

Aos meus colegas da Odontopediatria Natália, Bianca, Anna Paola, Maiara, Matheus e Giuliana, pela descontração e pela troca de conselhos!

A minha aluna de Iniciação Científica Giovanna Mosella Pegatin, por fazer além do necessário e se dedicar tanto ao projeto!

A Franciny Querobim Ionta, minha eterna orientadora de IC, obrigada pela paciência e por me ajudar tanto há tantos anos. Você sempre foi uma inspiração pra mim! Muito obrigada por todo carinho!

Ao Prof. Heitor Marques Honório, pela oportunidade de assistir às aulas de estatística e pelas análises deste trabalho!

Aos demais professores do Departamento de Odontopediatria, Profa. Dra. Thais Marchini de Oliveira Valarelli, Profa. Dra. Maria Aparecida de Andrade Moreira Machado, Prof. Dr. Natalino Lourenço Neto e Prof. Dr. Thiago Cruvinel da Silva.

A Estelinha e Lilian, que tanto nos ajudam nas clínicas, não só profissionalmente, estando lá dia a dia com sorriso no rosto esperando por nós!

As crianças da Odontopediatria que tanto me ensinam sobre a vida, que deixam tudo mais leve e divertido e me deram o prazer de atender durante o Mestrado!

A CAPES por me conceder a bolsa que viabilizou meus estudos.

A Faculdade de Odontologia de Bauru da Universidade de São Paulo por toda infraestrutura, recursos, apoio e oportunidades oferecidas desde minha graduação. Obrigada por ser minha segunda casa!

A banca examinadora, por terem aceitado esse convite, pelas críticas e conselhos.

Por fim, a todos aqueles que, de alguma forma, me apoiaram e acreditaram em mim para a realização deste trabalho! 

"Seja a mudança que você quer ver no mundo" Mahatma Gandhi 



\begin{abstract}
Performance of giomer-based resin composites under erosive wear and their influence on the adjacent enamel alteration: in vitro study

BERGANTIN, Bianca Tozi Portaluppe. Performance of giomer-based resin composites under erosive wear and their influence on the adjacent enamel

alteration: in vitro study. 2019. 51 p. Dissertação (Mestrado em Ciências Odontológicas Aplicadas) - Faculdade de Odontologia de Bauru, Universidade de São Paulo, Bauru, 2019.
\end{abstract}

Erosive tooth wear is a permanent loss of hard dental tissue by the frequent action of chemical and mechanical challenges. This condition has shown an increase in its prevalence in recent years, requiring intervention in the process, ideally through preventive therapies, however, these lesions often need restorative therapies. The objective of this study was to evaluate the use of Giomer-based composites under conditions of erosive tooth wear and their effect on adjacent enamel compared to conventional resin composites and glass ionomer cements by means of an in vitro evaluation, taking into account their differentiated recharge and fluoride release technology, satisfactory aesthetics and resistance and their ability to neutralize acid $\mathrm{pH}$. For that, 120 specimens of bovine teeth were obtained, selected and randomly distributed in 12 groups ( $\mathrm{n}=10$ ): GI: GRe - Composite Nano-Hybrid Resin with Giomer technology (EROSION); GIl: GRa - Composite Nano-Hybrid resin with Giomer technology (EROSION + ABRASION); GIII: GBe - Resin Composed of single increment with Giomer technology (EROSION); GIV: GBa - Composite resin of single increment with Giomer technology (EROSION + ABRASION); GV: RCe - Micro-Hybrid Composite Resin (EROSION); GVI: RCa - Micro-Hybrid Composite Resin (EROSION + ABRASION); GVII: RBe - Single-increment Micro-Hybrid Composite Resin (EROSION); GVIII: RGa - Single-increment Micro-Hybrid Composite Resin (EROSION + ABRASION); GIX: CGle - Conventional Glass lonomer Cement - CIVC (EROSION); GX: CGla - Conventional Glass lonomer Cement - CIVC (EROSION + ABRASION); GXI: RMGle - Resin Modified Glass lonomer Cement - CIVMR (EROSION); GXII: RMGla - Resin Modified Glass lonomer Cement - CIVMR (EROSION + ABRASION). 

In each enamel specimen a cavity was made and the restorative material was inserted under study according to the manufacturer's specifications. The initial profile was then performed, with scans of the material and the adjacent enamel (at 100, 200, 300, 600 and $700 \mu \mathrm{m}$ ). During 5 days, 6 erosive challenges were performed with citric acid for 2 minutes and in the EROSION + ABRASION groups the brushing was performed for 1 minute in a simulated brushing machine, immediately after erosion and washing. Subsequently the final profile was made in the same locations of the initial, for graphic overlap and analysis of loss of material and enamel. Data were evaluated by two-way ANOVA and then the Tukey test was used for comparison between groups, considering $\alpha<0,05$. When subjected to erosion, the CGle and RMGle groups presented greater loss of material compared to the other groups. Up to $300 \mu \mathrm{m}$ away from the restoration, the GIC groups and Giomer-based composites were able to promote less enamel loss than the conventional composite. For erosion associated to abrasion, Giomer-based composites showed intermediate loss of material, with greater loss in ionomeric groups and lower loss in conventional composite, with no difference between adjacent enamel in these conditions. It was concluded that Giomer-based resin composites are a good alternative for restorative treatment of erosion lesions.

Keywords: Dental Erosion. Tooth Wear. Dental Materials. 



\section{RESUMO}

BERGANTIN, Bianca Tozi Portaluppe. Desempenho de resinas compostas a base de giomer submetidas ao desgaste erosivo e sua influência na alteração do esmalte adjacente: estudo in vitro. 2019. 51 p. Dissertação (Mestrado em Ciências Odontológicas Aplicadas) - Faculdade de Odontologia de Bauru, Universidade de São Paulo, Bauru, 2019.

O desgaste dentário erosivo é a perda permanente de tecido dental duro pela ação frequente de desafios químico e mecânico. Essa condição vem apresentando um aumento na sua prevalência nos últimos anos, necessitando intervenção no processo idealmente por meio de terapias preventivas, entretanto, muitas vezes essas lesões necessitam de terapias restauradoras. $O$ objetivo deste estudo foi avaliar a utilização de resinas a base de tecnologia Giomer, sob condições de desgaste dentário erosivo e seu efeito no esmalte adjacente em comparação com a resina composta convencional e cimento de ionômero de vidro por meio de uma avaliação in vitro, levando em conta sua tecnologia diferenciada de recarga e liberação de flúor, estética e resistência satisfatórias e sua capacidade de neutralizar o pH ácido. Para tanto, 120 espécimes de dentes bovinos foram obtidos, selecionados e randomicamente distribuídos em 12 grupos ( $n=10$ ): Gl: GRe - Resina Composta Nano-Híbrida com tecnologia Giomer (EROSÃO); GII: GRa - Resina Composta Nano-Híbrida com tecnologia Giomer (EROSÃO + ABRASÃO); GIII: GBe - Resina Composta de incremento único com tecnologia Giomer (EROSÃO); GIV: GBa - Resina Composta de incremento único com tecnologia Giomer (EROSÃO + ABRASÃO); GV: RCe Resina Composta Micro Híbrida (EROSÃO); GVI: RCa - Resina Composta Micro Híbrida (EROSÃO + ABRASÃO); GVII: RBe -Resina Composta Micro Híbrida de incremento único (EROSÃO); GVIII: RBa - Resina Composta Micro Híbrida de incremento único (EROSÃO + ABRASÃO); GIX: CGle - Cimento de lonômero de Vidro Convencional - CIVC (EROSÃO); GX: CGla - Cimento de lonômero de Vidro Convencional - CIVC (EROSÃO + ABRASÃO); GXI: RMGle - Cimento de lonômero Vidro Modificado por Resina - CIVMR (EROSÃO); GXII: RMGla - Cimento de lonômero Vidro Modificado por Resina - CIVMR (EROSÃO + ABRASÃO). Em cada 

espécime de esmalte foi confeccionada uma cavidade e inserido o material restaurador em estudo de acordo com as especificações do fabricante. A seguir foi realizado o perfil inicial, com varreduras no material e no esmalte adjacente (a 100, 200, 300, 600 e $700 \mu \mathrm{m}$ ). Durante 5 dias foram realizados 6 desafios erosivos com ácido cítrico durante 2 minutos e, posteriormente, nos grupos EROSÃO + ABRASÃO foi realizada a escovação por 1 minuto em uma máquina de escovação simulada, imediatamente após a erosão e lavagem. Posteriormente foi feito o perfil final nos mesmos locais do perfil inicial, para sobreposição gráfica e análise de perda de material e esmalte. Os dados foram avaliados por meio do teste ANOVA a dois critérios e então foi feito o teste de Tukey para comparação entre os grupos, considerando $\alpha<0,05$. Quando submetido à erosão, os grupos CGle e RMGle apresentaram maior perda de material comparado aos outros grupos. Até $300 \mu \mathrm{m}$ de distância da restauração, os grupos de CIV e resinas a base de Giomer foram capazes de promover menor perda de esmalte que a resina convencional. Para erosão associada à abrasão, resinas a base de Giomer demonstraram perda de material intermediária, sendo vista uma maior perda nos grupos ionoméricos e menor perda na resina convencional, não havendo diferença entre o esmalte adjacente nessas condições. Conclui-se que resinas a base da tecnologia Giomer são uma boa alternativa para o tratamento restaurador de lesões de erosão.

Palavras-chave: Erosão Dentária. Desgaste Dentário. Materiais Dentários. 



\section{SUMÁRIO}

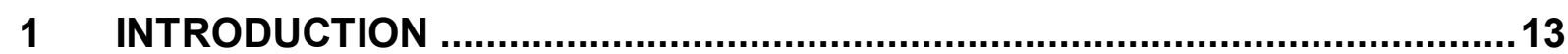

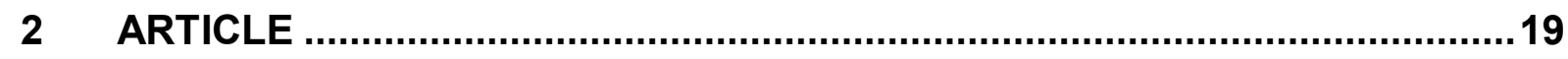

2.1. Performance of giomer-based resin composites under erosive wear and their influence on the adjacent enamel alteration: in vitro study ........19

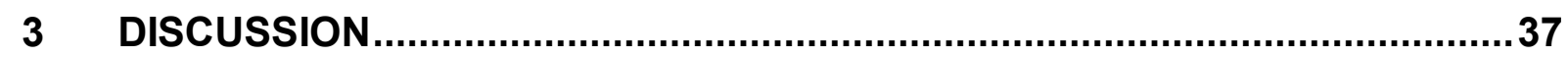

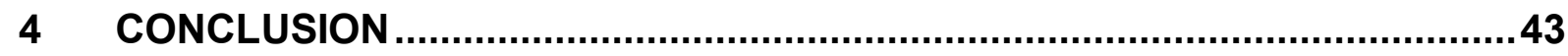

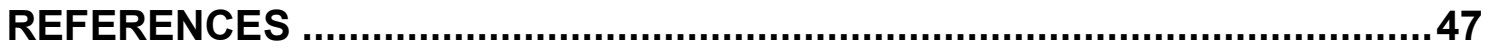





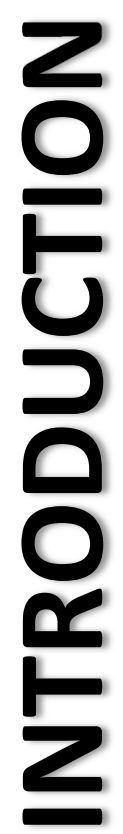





\section{INTRODUCTION}

Erosive tooth wear is defined as a chemical-mechanical process involving a gradual loss of dental hard tissue by the action of intrinsic and extrinsic acids of nonbacterial origin. The decrease in the local pH generates a mineral loss on the enamel surface, which leads to a superficial softening. This enamel softened by erosion is extremely brittle and more susceptible to mechanical forces, such as abrasion by brushing (GRIPPO; SIMRING; SCHREINER, 2004), which, when frequent, lead to such wear (TEN CATE; IMFELD, 1996; ATTIN et. al., 2000; CARVALHO et. al., 2015).

This condition has been showing an increase in its prevalence in recent years (SALAS et. al., 2015; TSCHAMMLER et. al., 2016; BRUSIUS et. al., 2017), probably because of a greater exposure to its causal factors. These factors are associated with the presence of acids of intrinsic origin, such as gastroesophageal reflux or bulimia, and acids of extrinsic origin, such as acidic foods and beverages. The quantity, frequency and mode of consumption of these acidic foods and beverages influence its erosive potential. In addition, medications and supplements may also be erosive when in the form of chewable tablets or effervescent tablets, because they have acidity and may in some cases promote a decrease in salivary flow (HELLWI; LUSSI, 2014).

Saliva is considered an individual erosion protection factor because of its ability to form a dental film acquired on the dental surface, dilute acids and neutralize oral $\mathrm{pH}$. Thus individual characteristics such as saliva are considered important factors in the etiology of dental erosion, since individuals exposed to similar erosive challenges present different tooth compromises, some of which do not present lesions of erosive dental wear, demonstrating that biological factors play a protective role crucial in the development of erosion lesions (LUSSI; CARVALHO, 2014; CARVALHO et. al., 2015).

In view of the greater exposure to causal factors that lead to an increase in the prevalence of dental erosion (NUNN et. al., 2003; LUSSI; CARVALHO, 2014), there is a need for intervention in the erosive process, ideally through preventive therapies that, as a priority, must be present when given the diagnosis of dental erosion (NUNN, 1996), by changing the patient's habits, reducing erosive challenges and increasing protective factors, restoring balance. However, it is observed a difficulty in interfering with these 
habits (LUSSI, 2006; SERRA; MESSIAS; TURSSI, 2009), leading to the progression of lesions and consequent need for restorative therapies (ZERO; LUSSI, 2005; LUSSI; CARVALHO, 2014), which are determined by the complexity of the case, varying according to the sequelae caused by erosive tooth wear, whether they are symptomatic, functional or aesthetic (PEUZFELDT; JAEGGI; LUSSI, 2014). With the advent and improvement of adhesive systems, these erosion lesions can be restored in a less invasive manner using materials such as glass ionomer cements (conventional and modified composite) and resin composites.

The choice of material should be related to the longevity of the restoration, which depends on the level of tooth destruction and the durability of the material, which is related to its properties, such as wear resistance or biodegradation and durability at the interface between tooth and restoration (PEUZFELDT; JAEGGI; LUSSI, 2014, ROLIM et. al., 2016). Additionally, depending on the area of the impacted tooth, ideally, the material should exhibit favorable aesthetic properties. In addition, an advantageous preventive feature would be the material ability to inhibit the erosion of the adjacent dental structure, helping to maintain the patient's oral health (PEUZFELDT; JAEGGI; LUSSI, 2014), similarly to caries lesions when applying glass ionomers cements (GIC), which, because of their ability to recharge and release fluoride, decrease the chance of recurrence of secondary caries around the restoration (TYRAS, 1991; FORSTEN, 1993; RIOS et. al., 2007; ALGHILAN et. al., 2015). In erosion, there are controversial results regarding the prevention of erosive wear around restorations, where we have some studies showing that there is less wear around GIC (ALGHILAN et. al., 2015; ROLIM et. al., 2016) and others showing no significant difference between materials (RIOS et. al., 2007; FRANCISCONI et. al., 2008).

Literature shows that restorative materials can also be affected by erosive acids, decreasing their clinical performance and longevity (HONÓRIO et. al., 2008; ALGHILAN et. al., 2015). The resin composite presents smaller changes in its surface under erosive challenges when compared to GIC, however, another important property to be observed is the adhesion and formation of micro infiltration of materials (HONÓRIO et. al., 2008), in which the Conventional GIC shows better results (WALIA et. al., 2016). 
There is on the market a group of restorative materials known as "Giomer" or pre-reactive glass ionomer (PRG) from SHOFU. Giomer's technology is characterized by hybrid glass ionomer compounds whose particles consists of pre-reactive fluorosilicate with polyacrylic acid and are incorporated into a composite matrix (KOOI et. al., 2012). Bonding agents bind the particles to the composite matrix and catalysts are added to initiate polymerization of the material (KOOI et. al., 2012). These materials require adhesive and photopolymerization agents, are easy to handle (KOOI et. al., 2012), with various physical and chemical properties, such as anti-plaque effect reducing the risk of caries (NISHIO; YAMAMOTO, 2002; YONEDA et. al., 2012; YONEDA; SUZUKI; HIROFUJI, 2015), releasing and recharging of fluoride (TOKUNAGA et. al., 2013; GORDAN et. al. 2014; SUZUKI et. al., 2015), maintenance of their long-term properties and resistance (KUROKAWA et. al., 2015) restoring function (AKIMOTO et. al., 2011) and aesthetics (NAKAMURA et. al., 2009), besides their ability to neutralize acidic $\mathrm{pH}$, preventing demineralization of new subsurface lesions of caries their surrounding (SHIIYA et. al., 2012; SHIMAZU; OGATA; KARIBE, 2012; KAGA et. al., 2014; KAWASAKI; KAMBARA, 2014; SHIRAI et. al., 2015). Considering this last property, this material could be beneficial to patients with dental erosion, because its use could prevent new lesions around these restorations, due to their ability to neutralize the acidic $\mathrm{pH}$, so there would be an action in the acid and not in the structure of enamel, different from the mechanism of action of fluorides. However, the use of Giomer as restorative material in erosion lesions is still unknown. Thus, the aim of this study was to evaluate the effect of giomer technology on the enamel adjacent to the material and the wear of the material itself subjected to erosive and abrasive challenges compared to the resin composite and glass ionomer cement by means of an in vitro evaluation. 

$\frac{1}{4}$ 



\title{
2 ARTICLE
}

The article presented in this Dissertation was written according to the Journal of Dentistry instructions and guidelines for article submission.

- Performance of giomer-based resin composites under erosive wear and their influence on the adjacent enamel alteration: in vitro study

\begin{abstract}
This in vitro study evaluated the resistance of giomer-based resin composites against erosive wear and their protective effect on enamel adjacent to restoration. Bovine enamel blocks were randomized into 12 groups $(n=10)$ : giomer-based composite resinBeautiful $\| ®$ (Gioe/Gioa); giomer-based bulk-fill resin-Beautiful Bulk Restorative $®$ (GioBFe/GioBFa); resin composite -Filtek Z350 XT® (RCe/RCa); bulk-fill composite resinFiltek Bulk Fill $\left(B F e\right.$ and BFa); glass ionomer cement-EQUIA Forte ${ }^{\circledR}$ (GICe/GICa); Resinmodified glass ionomer cement-Riva (RMGle/RMGla). Group followed by "e" was subjected to erosion and by "a" to erosion+abrasion. Specimens were prepared and restored according to the manufacturers' instructions. The initial profile was performed on the material and on the adjacent enamel (100, 200, 300, 600 and $700 \mu \mathrm{m})$. During 5 days, $6 x /$ day specimens were immersed in citric acid for 2 minutes, and abrasive challenge was performed using a toothbrushing machine for 1 minute. Final profile was obtained for material and/or enamel loss measurement. Data were evaluated by two-way ANOVA and Tukey test $(\alpha<0.05)$. When subjected to erosion, the GICe and RMGle groups presented greater loss of material compared to the other groups. Up to $300 \mu \mathrm{m}$ away from the restoration, GICe and GioBFe were able to promote less enamel loss than the resin groups. For erosion+abrasion there was no difference of enamel wear adjacent to the studied materials among the materials, giomer-based groups showed intermediate material wear compared to GIC (higher wear) and resin composite (less wear). It is concluded that Giomer-based composites are a good alternative for restorative treatment of erosive tooth wear.
\end{abstract}

Clinical Significance: Giomer-based composites are able to diminish enamel wear due to erosion near to the restoration, similarly to glass ionomer cement with the vantage of being more resistant to erosive challenge. Therefore, this material is a potential option to restore advanced erosion lesions in patients with etiological factors still present. 
Keywords: Dental Erosion. Tooth Wear. Dental Materials.

\section{Introduction}

Erosive tooth wear (ETW) corresponds to a tooth tissue destroy due to chemical-mechanical process, in which extrinsic (dietary) and intrinsic (gastric) acids interacts with attrition and/or abrasion [1]. The prevalence of this alteration is high and there is a suspicion of increasing [2 - 4]. The ideal treatment for ETW is based on early diagnoses and implementation of non-operative management strategies, acting on the risk factors for its development over time $[5,6]$. When risk factors are not effectively controlled, the enamel, and eventually the dentine, is lost. According to the Radboud philosophy, even for patients with severe tooth wear, when there is no complaints, counselling and monitoring is the treatment of choice. Restorative treatment is not always necessary, but when there is loss of vertical dimension of occlusion and/or loss of esthetics, minimally invasive and adhesive restorative strategies are indicated [7].

The longevity of restorative materials under erosive and abrasive challenges depends on durability of the material and durability of the interface between tooth substance and restoration [8]. The chemical-mechanical resistance of glass ionomer cements (GIC) is lesser than resin composite [9]. On the other hand, GICs are able to release fluoride, which could enhance the acid resistance of the tooth tissue adjacent to restorations $[10,11]$. Therefore, there is no ideal bioactive material with potential benefits as resistance and preventive effects.

Giomer's technology is based on Surface Pre-Reacted Glass-ionomer (S-PRG) fillers that are synthesized by the reaction between fluoro-boro-aluminosilicate glass and a polyacrylic acid solution [12]. This material has shown to release multiple ions including $\mathrm{F}^{-}, \mathrm{Sr}^{2+}, \mathrm{Na}^{+}, \mathrm{BO}_{3}{ }^{3-}, \mathrm{Al}^{3+}$, and $\mathrm{SiO}_{3}{ }^{2-}[13,14]$. The ion release promotes acid buffering action in the low $\mathrm{pH}$ lactic acid solution [15] and prevents demineralization around the material [16 - 21]. This filler is used in various dental materials including composite resins, in which bonding agents bind the particles with composite matrix and catalysts are added to initiate polymerization of the material [16]. The buffering effect and the potential to prevent demineralization might be good characteristics of a material aiming to diminish the occurrence of enamel loss around restorations in patients with the presence of etiological factors for the development of erosion. However, there are no studies testing the chemical mechanical resistance of this 
material or even its ability to prevent tooth tissue loss due to erosion. Therefore, this in vitro study aimed to evaluate the performance of giomer-based resin composites under erosion and abrasion and their influence on the adjacent enamel alteration. The null hypothesis formulated is that: 1) giomer-based composites present less loss when subjected to erosive and abrasive challenges compared to resin composites and glass ionomer cements; and 2) giomer-based composites are not able to prevent enamel wear adjacent to the restoration, when subjected erosion and abrasion.

\section{Material and Methods}

\section{Experimental Design}

The factors under study were type of material (four levels) and wear condition (two levels). One hundred and twenty crowns of bovine teeth composed the sample, the specimens were randomly assigned into 12 groups $(n=10)$ : giomer-based composite resin-Beautiful $I \circledast$ (Gioe/Gioa); giomer-based bulk-fill resin-Beautiful Bulk Restorative ${ }^{\circledR}$ (GioBFe/GioBFa); composite resin-Filtek Z350 XT® (RCe/RCa); bulk-fill composite resin-Filtek Bulk Fill $(\mathrm{RBe}$ and $\mathrm{RBa})$; glass ionomer cement-EQUIA Forte $®$ (GICe/GICa); Resin-modified glass ionomer cement-Riva® (RMGle/RMGle). Group followed by "e" was subjected to erosion and by "a" to erosion+abrasion.

Circular cavities were prepared on each specimen and then restored according to manufacturers' instructions (Table 1). During 5 days, erosion was simulated in vitro (Groups e) by specimens' immersion in citric acid for $2 \mathrm{~min}$, 6X/day. For groups subjected to erosion associated to abrasion (Groups a), each erosive challenge was followed by abrasion using a toothbrush machine with fluoridated dentifrice slurry (3:1) for $60 \mathrm{~s}$. Between challenges, the blocks were kept in artificial saliva. The response variable was material and enamel loss measured by profilometry.

Specimen preparation

Approximately 140 bovine teeth were used in the present study. First the roots were separated from their crowns using a cutting machine (National Factory of Nevoni Single-phase Motors / Series 16.223, Type: TG1 / 3, São Paulo, SP) and a diaflex-F (Wilcos do Brasil, Indústria e Comércio Ltda., Petrópolis, RJ) diamond disc. Crowns were individually placed in a silicone cylindrical mold (inner radius of $2.8 \mathrm{~cm}$ ) and embedded in acrylic resin (Jet Ltd, Campo Limpo Paulista, SP, Brazil). Then, the specimens were ground flat with water-cooled silicon carbide discs $(600$, and 1200 
grades of Al2O3 paper; Buehler Ltd) and polished with felt paper wet by $1 \mu \mathrm{m}$ diamond spray (1 $\mu \mathrm{m}$; Buehler Ltd., Lake Bluff, IL, USA Buehler Ltd). The enamel specimens were ultrasonicated in deionized water for 2 min (Ultrasonic Cleaner Mod USC 750, Unique Ind. And Com. Ltda, São Paulo, SP) between the polishing steps.

One profile per specimen was performed to ascertain their planning, eliminating those with curvature and selecting 120 specimens. The profile was obtained with contact profilometer (Mahr Perthometer, Göttingen, Germany), coupled to a computer with a MarSurf XCR 20 contour software. Then, a random distribution was made using the Microsoft Excel program, using the "RANDOM" function of the mathematical category (10 specimens per group, 12 groups).

Circular cavities were prepared at the center of the crown using \#2096 cylindrical drill (KG Soresen, São Paulo, Brazil), with a diameter of $1.4 \mathrm{~mm}$. An automatic device specially designed for this was used to standardize the depth of preparation $(1.5 \mathrm{~mm})$. Each material was handled according to the manufacturer's instructions (Table 1). For the resin composite groups the same $37 \%$ phosphoric acid (Condac 37 FGM / Lot 1301317) and adhesive system were applied (ESPE Single Bond Universal 3M / Lot 643238). 
Table 1 - Restoration's instructions of each material.

\begin{tabular}{|c|c|c|c|}
\hline MATERIAL/LOT/COLOR & GROUP & COMPOSITION & APPLICATION STEPS \\
\hline $\begin{array}{c}\text { Beautifil II } \\
\text { Lot } \mathbf{0 5 1 8 2 9} \text { / Color A2 }\end{array}$ & $\begin{array}{c}\text { Giomer-based } \\
\text { Composite Resin } \\
\text { (Gio) }\end{array}$ & $\begin{array}{c}\text { Bis-GMA, TEGDMA, } \\
\text { multifunctional filler, S- } \\
\text { PRG filler based on F- } \\
\text { Br-Al-Si glass }\end{array}$ & \multirow{3}{*}{$\begin{array}{l}37 \% \text { phosphoric acid* (15 s), } \\
\text { rinsing and drying, Universal } \\
\text { Adhesive** }(20 \mathrm{~s}) \text {, drying ( } 5 \\
\text { s), light curing***, insertion } \\
\text { of the material and light } \\
\text { curing (10 s). }\end{array}$} \\
\hline $\begin{array}{c}\text { Beautifil Bulk } \\
\text { Restorative }^{\circledR} \\
\text { Lot } 031828 \text { / Color } \\
\text { Universal }\end{array}$ & $\begin{array}{l}\text { Giomer-based } \\
\text { Bulk-Fill Resin } \\
\text { (GioBF) }\end{array}$ & $\begin{array}{c}\text { Bis-GMA, UDMA, Bis- } \\
\text { MPEPP, TEGDMA, S- } \\
\text { PRG based on F-Br-Al-Si } \\
\text { glass }\end{array}$ & \\
\hline $\begin{array}{c}\text { Filtek One }^{\mathrm{TM}} \text { Bulk Fill }^{\circledR} \\
\text { Lot N963374 / Color } \\
\text { A2 }\end{array}$ & $\begin{array}{c}\text { Bulk-Fill } \\
\text { Composite Resin } \\
\text { (RB) }\end{array}$ & $\begin{array}{l}\text { AFM, DDDMA, UDMA, } \\
\text { AUDMA, pocrylat } \\
\text { resins, ytterbium } \\
\text { trifluoride, zirconia/ } \\
\text { silica cluster }\end{array}$ & \\
\hline $\begin{array}{l}\text { Filtek }^{\mathrm{TM}} \text { Z350 XT }{ }^{\circledR} \\
\text { Lot } 1710900734 \text { / } \\
\text { Color A2 Dentin }\end{array}$ & $\begin{array}{c}\text { Composite Resin } \\
\text { (RC) }\end{array}$ & $\begin{array}{c}\text { Bis-GMA, Bis-EMA, } \\
\text { UDMA, TEGDMA, } \\
\text { zirconia/silica cluster } \\
\text { and silica nanoparticle }\end{array}$ & $\begin{array}{c}37 \% \text { phosphoric acid* (15 s), } \\
\text { rinsing and drying, Universal } \\
\text { Adhesive** }(20 \mathrm{~s}) \text {, drying ( } 5 \\
\text { s), light curing***, insertion } \\
\text { of the material and light } \\
\text { curing ( } 40 \mathrm{~s}) .\end{array}$ \\
\hline $\begin{array}{c}\text { EQUIA Forte }^{\circledR} \\
\text { Lot } 1709191 \text { / Color A2 }\end{array}$ & $\begin{array}{l}\text { Glass Ionomer } \\
\text { Cement (GIC) }\end{array}$ & $\begin{array}{l}\text { Powder: F-Al-Si glass, } \\
\text { Polyacrylic acid } \\
\text { powder, pigment. } \\
\text { Liquid: Polyacrylic acid, } \\
\text { distilled water, } \\
\text { polybasic carboxylic } \\
\text { acid }\end{array}$ & $\begin{array}{l}26 \% \text { polyacrylic acid }{ }^{\#}(10 \mathrm{~s}), \\
\text { rinsing and drying, capsule } \\
\text { agitation }(10 \mathrm{~s}), \text { material } \\
\text { application, chemical } \\
\text { polymerization }(3 \mathrm{~m}), \\
\text { protector application }{ }^{\#} \text { and } \\
\text { polymarization }(20 \mathrm{~s}) .\end{array}$ \\
\hline $\begin{array}{l}\text { RIVA Light Cure }{ }^{\circledR} \text { / Lot } \\
\text { J1602181EG / Color A2 }\end{array}$ & $\begin{array}{l}\text { Resin-Modified } \\
\text { Glass Ionomer } \\
\text { Cement (RMGI) }\end{array}$ & $\begin{array}{l}\text { Powder: F-Al-Si glass. } \\
\text { Liquid: polyacrylic acid, } \\
\text { HEMA and tartaric acid }\end{array}$ & $\begin{array}{c}26 \% \text { polyacrylic acid }{ }^{\#}(10 \mathrm{~s}) \text {, } \\
\text { rinsing and drying, capsule } \\
\text { agitation (10 s), material } \\
\text { application, light curing*** } \\
(20 \mathrm{~s}) .\end{array}$ \\
\hline
\end{tabular}

Abbreviations: Bis-GMA (bisphenol A-glycidyl methacrylate), TEGDMA (triethylene glycol dimethacrylate), $\mathrm{F}$ (fluoride), Br (boron), Al (aluminium), Si (silicate), UDMA (Urethane Dimethacrylate), Bis-MPEPP (BisphenolA polyethoxy-dimethacrylate), AFM (ddition-fragmentaion monomers), DDDMA (1,12-dodecanediol dimethacrylate), AUDMA (Aromatic urethane dimethacrylate), HEMA (2-hydroxyethyl methacrylate).

* Condac 37 FGM / Lot 1301317

** Adper Single Bond Universal 3M-ESPE / Lot 643238

*** Dabi Atlante / LED 1,400 mW / cm ${ }^{2}$

\#\# Equia Forte Coat Protector (Lot 1702081)

\#RIVA Conditioner / Lot 170705 
After 7 days of storage at $37^{\circ} \mathrm{C}$ in $100 \%$ relative humidity, the restorations were ground flat with water-cooled silicon carbide discs as described before.

Initial Profilometric Analysis

Enamel blocks were marked with a scalpel blade (Embramac, Itapira, SP, Brazil) at two opposite sites with a distance of $0.3 \mathrm{~mm}$ from the margin of the restoration, resulting in two reference areas with $1.0 \mathrm{~mm}$ (at the border) and a test area with 2.0 $\mathrm{mm}$, containing the restoration (at the center). Subsequently, initial surface profiles were obtained from the specimens using a profilometer (MarSurf GD 25, Göttingen, Germany) and a contour software as described above. To standardize their position, specimens were fixed to a special holder and their locations were recorded allowing their exact replacement after the erosive challenges. To analyze restorative material loss, two surface profiles were obtained through scanning from the reference to the test area, at the center of the restoration with a distance of $100 \mu \mathrm{m}$ between them. On the other hand, to analyze enamel loss adjacent to restoration, five profiles were obtained through scanning from the reference to the test area, at $100-200-300$ 600 and $700 \mu \mathrm{m}$ distant from the restoration margin.

Then, the previously demarcated control areas were protected with cosmetic nail varnish (Colorama Maybelline - Ultra Dura, Cobra Cosméticos Ltda, São Paulo, SP, Brazil) to maintain the integrity of the control reference area during erosive and/or abrasive challenges.

$\underline{\text { In vitro erosive and abrasive challenges }}$

Extra-soft toothbrushes (Colgate Twister ${ }^{\circledR}$, Colgate Palmolive Industrial LTDA, S.B. Campo, Brazil) $(\mathrm{n}=60)$ were cut $7 \mathrm{~cm}$ distant from the last bristle using a cutting machine with a diamond disk (National Factory of Nevoni Single-phase Motors I Series 16.223, Type: TG1 / 3, São Paulo, SP and a diaflex-F / Wilcos do Brasil, Indústria e Comércio Ltda., Petrópolis, RJ). The slurry solution was prepared daily by diluting fluoride dentifrice (Colgate triple action $\AA$, Colgate-Palmolive Industrial LTDA, SB Campo, Brazil) in distilled water in the proportion 1: 3 (weight-volume ratio, according to ISO 14569 -1), and was always agitated before being used.

All the specimens were subjected to six erosive cycling daily for 5 days, by their immersion in $30 \mathrm{ml}$ of $0.5 \%$ citric acid pH 2.5 for 2 minutes under agitation at a speed of $50 \mathrm{rpm}$ and at a controlled temperature of $25^{\circ} \mathrm{C}$. For the groups in which erosion was associated with abrasion, the abrasive cycling was performed $6 \mathrm{x} /$ day for 5 days, always shortly after the erosive cycling. Toothbrushes were personalized for each 
specimen and fixed parallel to the dental surface on a brushing machine (Dental Biopdi, São Carlos, SP, Brazil). The dentifrice slurry was automatic dropped on each specimen $(\approx 3 \mathrm{ml})$. Each abrasive cycling consist of brushing the specimens for $60 \mathrm{~s}$ with 100 reciprocal linear motion (back and forth) and force of $250 \mathrm{~g}$, at temperature of $37.5^{\circ} \mathrm{C}$. After abrasion, specimens were rinsed with deionized water for $5 \mathrm{~s}$ and kept immersed in artificial saliva $(0.33 \mathrm{~g} \mathrm{KH2PO} 4,0.34 \mathrm{~g} \mathrm{Na} 2 \mathrm{HPO} 4,1.27 \mathrm{~g} \mathrm{KCl}, 0.16 \mathrm{~g} \mathrm{NaSCN}, 0.58 \mathrm{~g}$ $\mathrm{NaCl}, 0.17 \mathrm{~g} \mathrm{CaCl} 2,0.16 \mathrm{~g} \mathrm{NH} 4 \mathrm{Cl}, 0.2 \mathrm{~g}$ urea, $0.03 \mathrm{~g}$ glucose, $0.002 \mathrm{~g}$ ascorbic acid, pH 7 (KLIMEK et al., 1982 modified without mucin) [22], for 2 hours, until the next cycling. At the end of each day of cycling, the specimens were also immersed in artificial saliva, overnight (14 hours), under a temperature of $37^{\circ} \mathrm{C}$.

\section{Profilometric Analysis}

After the in vitro erosive and abrasive cycling, the cosmetic nail varnish was removed from the reference areas and the profilometric analysis was performed at the same sites of the initial measurements. Baseline and final profiles were perfectly matched, since the enamel specimens could be precisely repositioned in the profilometer wells. The material and enamel loss was quantitatively determined using a specific software (MarSurf XCR 20) by calculating the vertical difference (average depth of the surface) between baseline and final surface profiles. The material loss corresponded to the average value of the two profiles made at the center of the material. On the other hand, the enamel loss was analyzed in each evaluated distance from the restoration margin.

\section{Statistical analysis}

The assumptions of equality of variances and normal distribution of errors were satisfied. Two-way ANOVA and Tukey test were applied to analyze materials loss as well as the enamel loss in each distance in relation to the restoration. The significance level adopted was 5\% and the software used was Sigma Plot for Windows version 11.0 (Germany).

\section{Results}

Table 2 shows the results for material loss. A statistic difference was found for type of material $(\alpha=0.000)$, for condition $(\alpha=0.000)$ and their interaction was also significant $(\alpha=0.000)$. When considering the erosion condition the composite groups and the giomer-based composite groups presented statistic similar material loss, which 
was less than that of the glass ionomer cement groups. On the erosion + abrasion condition the composite groups presented less material loss, followed by giomer-based composite and then by the ionomer groups, with statistic difference among them. Considering each material, both glass ionomers and both giomer-based composites showed higher material loss when erosion was associated to abrasion in comparison to erosion alone. The composite groups presented statistic similar material loss when subjected to erosion and erosion + abrasion conditions.

Table 2 - Average wear on material $(\mu \mathrm{m})$ and standard deviation $(\mathrm{Sd})$ of the study groups.

\begin{tabular}{|c|c|c|c|c|c|c|}
\hline $\begin{array}{l}\text { MATERIAL } \\
\text { CONDITION - }\end{array}$ & $\begin{array}{c}\text { Giomer } \\
\text { Beautiful II }^{\circledR}\end{array}$ & $\begin{array}{c}\text { Giomer - } \\
\text { Beautiful Bulk } \\
\text { Restorative }^{\circledR}\end{array}$ & 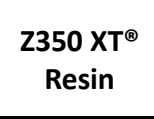 & Bulk Fill Resin & EQUIA Forte $^{\circledR}$ & RIVA LC ${ }^{\circledR}$ \\
\hline ERO & $1.7( \pm 0.7)^{\mathrm{a}}$ & $1.3( \pm 1.0)^{\mathrm{a}}$ & $0.6( \pm 0.4)^{a}$ & $1.1( \pm 0.8)^{\mathrm{a}}$ & $7.5( \pm 4.6)^{b, c}$ & $11.3( \pm 5.5)^{\mathrm{c}}$ \\
\hline ERO+ABR & $7.2( \pm 1.6)^{\mathrm{b}, \mathrm{c}}$ & $6.7( \pm 2.9)^{b}$ & $0.9( \pm 0.7)^{\mathrm{a}}$ & $1.5( \pm 0.8)^{\mathrm{a}}$ & $19.9( \pm 3.0)^{d}$ & $17.9( \pm 4.7)^{\mathrm{d}}$ \\
\hline
\end{tabular}

Different letters indicate statistical difference among group and conditions (two-way ANOVA and Tukey test).

ERO: erosion condition and ERO + ABRA: erosion and abrasion condition.

Tables 3, 4, 5, 6 and 7 show the results for enamel loss at 100, 200, 300, 600 and $700 \mu \mathrm{m}$ of distance from restoration margin, respectively. There was statistic difference for type of material, for condition and significant interaction on each distance. For erosion associated to abrasion condition, it was observed the same behavior of the groups on all studied distances, there was no statistic difference among groups in relation to enamel wear. When considering each material singly, the same differences between conditions on studied distances were observed. All materials resulted in higher enamel loss when erosion was associated to abrasion compared to erosion alone, except Z350 resin, which did not show any difference between the conditions (ERO and $E R O+A B R)$. When considering erosion, materials behavior was different on the studied enamel distances from the restoration margin.

At $100 \mu \mathrm{m}$, on erosion condition the Giomer Beautiful Bulk and EQUIA groups promoted less enamel wear than the Z350 and Bulk Fill, but were statistic similar to Giomer Beautiful II and Riva LC, those 2 groups were also similar to Bulk Fill. 
Table 3 - Enamel wear $(\mu \mathrm{m})$ and standard deviation $(\mathrm{Sd})$ of the studied groups on the distance of $100 \mathrm{~m} \mu$ from the restoration margin.

\begin{tabular}{|c|c|c|c|c|c|c|}
\hline CONDITION & $\begin{array}{c}\text { Giomer } \\
\text { Beautiful II® }\end{array}$ & $\begin{array}{c}\text { Giomer - } \\
\text { Beautiful Bulk } \\
\text { Restorative }^{\circledR}\end{array}$ & $\begin{array}{l}\text { Z350 XT® } \\
\text { Resin }\end{array}$ & Bulk Fill Resin & EQUIA Forte ${ }^{\circledR}$ & RIVA LC ${ }^{\oplus}$ \\
\hline ERO & $30.3( \pm 3.4)^{b, d}$ & $28.3( \pm 2.5)^{b}$ & $38.3( \pm 4.0)^{\mathrm{c}, \mathrm{e}}$ & $35.6( \pm 2.8)^{\mathrm{d}, \mathrm{e}}$ & $27.7( \pm 1.2)^{b}$ & $31.4( \pm 2.9)^{\mathrm{b}, \mathrm{d}}$ \\
\hline ERO+ABR & $44.1( \pm 5.2)^{\mathrm{a}, \mathrm{c}}$ & $44.6( \pm 5.0)^{a}$ & $43.2( \pm 4.4)^{a, c}$ & $47.1( \pm 4.6)^{\mathrm{a}}$ & $43.7( \pm 3.0)^{a, c}$ & $47.3( \pm 6.7)^{\mathrm{a}}$ \\
\hline
\end{tabular}

Different letters indicate statistical difference (two-way ANOVA and Tukey test, $p<0.05$ )

Material $(p=0.00002)$, condition $(p=0.000)$ and significant interaction $(p=0.00007)$

ERO: erosion condition and ERO + ABRA: erosion and abrasion condition.

At $200 \mu \mathrm{m}$ of distance, considering erosion condition, both giomer-based composites (Beautiful and Beautiful Bulk) groups and EQUIA (conventional GIC) group promoted statistic similar enamel loss, which was less when compared to Z350 group. Bulk Fill group was statistic similar to giomer-based composite groups. Riva LC was similar to both composite groups.

Table 4 - Enamel wear $(\mu \mathrm{m})$ and standard deviation $(\mathrm{Sd})$ of the studied groups on the distance of $200 \mathrm{~m} \mu$ from the restoration margin.

\begin{tabular}{c|c|c|c|c|c|c}
\begin{tabular}{c|c} 
MATERIAL \\
CONDITION
\end{tabular} & $\begin{array}{c}\text { Giomer } \\
\text { Beautiful II }^{\circledR}\end{array}$ & $\begin{array}{c}\text { Giomer - } \\
\text { Beautiful Bulk } \\
\text { Restorative }^{\circledR}\end{array}$ & $\begin{array}{c}\text { Z350 XT } \\
\text { Resin }\end{array}$ & Bulk Fill Resin & EQUIA Forte ${ }^{\circledR}$ & RIVA LC $^{\circledR}$ \\
\hline ERO & $30.6( \pm 3.3)^{\mathrm{b}, \mathrm{c}}$ & $29.4( \pm 3.6)^{\mathrm{b}, \mathrm{c}}$ & $38.2( \pm 4.1)^{\mathrm{d}, \mathrm{e}}$ & $35.0( \pm 2.6)^{\mathrm{c}, \mathrm{e}}$ & $27.9( \pm 1.4)^{\mathrm{b}}$ & $32.1( \pm 3.0)^{\mathrm{b}, \mathrm{c}, \mathrm{e}}$ \\
\hline ERO+ABR & $44.2( \pm 5.1)^{\mathrm{a}, \mathrm{d}}$ & $45.5( \pm 6.5)^{\mathrm{a}}$ & $44.0( \pm 3.2)^{\mathrm{a}, \mathrm{d}}$ & $47.1( \pm 5.0)^{\mathrm{a}}$ & $43.9( \pm 2.3)^{\mathrm{a}, \mathrm{d}}$ & $47.0( \pm 6.9)^{\mathrm{a}}$
\end{tabular}

Different letters indicate statistical difference (two-way ANOVA and Tukey test, $p<0.05$ )

Material $(p=0.0002)$, condition $(p=0.000)$ and significant interaction $(p=0.001)$

ERO: erosion condition and ERO + ABRA: erosion and abrasion condition.

At $300 \mu \mathrm{m}$ of distance, on erosion condition, only Giomer Beautiful Bulk and EQUIA groups resulted in less enamel wear than the Z350, but both were statistic similar to Giomer Beautiful II, Riva LC and Bulk Fill. 
Table 5 - Enamel wear $(\mu \mathrm{m})$ and standard deviation $(\mathrm{Sd})$ of the studied groups on the distance of $300 \mathrm{~m} \mu$ from the restoration margin.

\begin{tabular}{c|c|c|c|c|c|c}
$\begin{array}{c}\text { MATERIAL } \\
\text { CONDITION }\end{array}$ & $\begin{array}{c}\text { Giomer } \\
\text { Beautiful II }^{\circledR}\end{array}$ & $\begin{array}{c}\text { Giomer - } \\
\text { Beautiful Bulk } \\
\text { Restorative }^{\circledR}\end{array}$ & $\begin{array}{c}\text { Z350 XT } \\
\text { Resin }\end{array}$ & Bulk Fill Resin & EQUIA Forte ${ }^{\circledR}$ & RIVA LC $^{\circledR}$ \\
\hline ERO & $30.9( \pm 3.5)^{\mathrm{b}, \mathrm{c}}$ & $29.7( \pm 4.5)^{\mathrm{b}}$ & $37.8( \pm 4.0)^{\mathrm{c}, \mathrm{d}, \mathrm{e}}$ & $34.4( \pm 2.6)^{\mathrm{b}, \mathrm{c}, \mathrm{e}}$ & $28.2( \pm 1.4)^{\mathrm{b}}$ & $33.1( \pm 2.2)^{\mathrm{b}, \mathrm{c}}$ \\
\hline ERO+ABR & $44.5( \pm 4.7)^{\mathrm{a}, \mathrm{d}}$ & $46.5( \pm 11.3)^{\mathrm{a}}$ & $41.9( \pm 4.6)^{\mathrm{a}, \mathrm{d}, \mathrm{e}}$ & $46.8( \pm 4.7)^{\mathrm{a}}$ & $44.2( \pm 2.0)^{\mathrm{a}, \mathrm{d}}$ & $46.9( \pm 8.1)^{\mathrm{a}}$
\end{tabular}

Different letters indicate statistical difference (two-way ANOVA and Tukey test, $p<0.05$ )

Material $(p=0.07)$, condition $(p=0.000)$ and significant interaction $(p=0.003)$

ERO: erosion condition and ERO + ABRA: erosion and abrasion condition.

At 600 and $700 \mu \mathrm{m}$ of distances, when considering erosion condition, there was no difference for enamel loss among the groups, except EQUIA that resulted in less enamel loss compared to Z350.

Table 6 - Enamel wear $(\mu \mathrm{m})$ and standard deviation $(\mathrm{Sd})$ of the studied groups on the distance of $600 \mathrm{~m} \mu$ from the restoration margin.

\begin{tabular}{c|c|c|c|c|c|c} 
MATERIAL & $\begin{array}{c}\text { Giomer } \\
\text { Beautiful II }\end{array}$ & $\begin{array}{c}\text { Giomer - } \\
\text { Beautiful Bulk } \\
\text { Restorative }^{\circledR}\end{array}$ & $\begin{array}{c}\text { Z350 XT } \\
\text { Resin }\end{array}$ & Bulk Fill Resin & EQUIA Forte ${ }^{\circledR}$ & RIVA LC $^{\circledR}$ \\
\hline ERO & $30.7( \pm 3.2)^{\mathrm{b}, \mathrm{c}}$ & $29.8( \pm 4.1)^{\mathrm{b}, \mathrm{c}}$ & $36.3( \pm 3.7)^{\mathrm{c}, \mathrm{d}}$ & $33.7( \pm 2.6)^{\mathrm{b}, \mathrm{c}}$ & $28.5( \pm 1.4)^{\mathrm{b}}$ & $33.9( \pm 2.4)^{\mathrm{b}, \mathrm{c}}$ \\
\hline ERO+ABR & $43.7( \pm 4.8)^{\mathrm{a}}$ & $43.6( \pm 7.3)^{\mathrm{a}}$ & $41.6( \pm 4.5)^{\mathrm{a}, \mathrm{d}}$ & $45.9( \pm 4.3)^{\mathrm{a}}$ & $44.4( \pm 2.3)^{\mathrm{a}}$ & $45.7( \pm 7.5)^{\mathrm{a}}$
\end{tabular}

Different letters indicate statistical difference (two-way ANOVA and Tukey test, $p<0.05$ )

Material $(p=0.03)$, condition $(p=0.000)$ and significant interaction $(p=0.009)$

ERO: erosion condition and ERO + ABRA: erosion and abrasion condition.

Table 7 - Enamel wear $(\mu \mathrm{m})$ and standard deviation (dp) of the studied groups on the distance of $700 \mathrm{~m} \mu$ from the restoration margin.

\begin{tabular}{c|c|c|c|c|c|c} 
MATERIAL & $\begin{array}{c}\text { Giomer } \\
\text { Beautiful II }\end{array}$ & $\begin{array}{c}\text { Giomer - } \\
\text { Beautiful Bulk } \\
\text { Restorative }^{\circledR}\end{array}$ & $\begin{array}{c}\text { Z350 XT } \\
\text { Resin }\end{array}$ & Bulk Fill Resin & EQUIA Forte ${ }^{\circledR}$ & RIVA LC $^{\circledR}$ \\
\hline ERO & $30.4( \pm 2.8)^{\mathrm{b}, \mathrm{c}}$ & $30.0( \pm 3.6)^{\mathrm{b}, \mathrm{c}}$ & $36.1( \pm 3.5)^{\mathrm{c}, \mathrm{d}}$ & $33.3( \pm 2.2)^{\mathrm{b}, \mathrm{c}}$ & $29.0( \pm 1.6)^{\mathrm{b}}$ & $34.2( \pm 2.4)^{\mathrm{b}, \mathrm{c}}$ \\
\hline ERO+ABR & $43.7( \pm 4.2)^{\mathrm{a}}$ & $43.2( \pm 8.2)^{\mathrm{a}}$ & $41.3( \pm 3.9)^{\mathrm{a}, \mathrm{d}}$ & $45.3( \pm 5.0)^{\mathrm{a}}$ & $44.6( \pm 2.4)^{\mathrm{a}}$ & $45.3( \pm 6.9)^{\mathrm{a}}$
\end{tabular}

Different letters indicate statistical difference (two-way ANOVA and Tukey test, $p<0.05$ )

Material $(p=0.08)$, condition $(p=0.000)$ and significant interaction $(p=0.008)$

ERO: erosion condition and ERO + ABRA: erosion and abrasion condition. 


\section{Discussion}

Many restorative materials have been tested regarding their resistance to erosion associated or not to abrasion [8, 23]. When restorative treatment is indicated for a patient with erosive tooth wear, the ideal management is to eliminate the causes before starting it $[5,6]$. However, this approach is not always feasible, implying that there is a need for bioactive materials capable of protecting the tooth structure. The results of the present study showed that the giomer-based composite materials were able to promote less loss of enamel located at $100 \mu \mathrm{m}$ distant from restoration margin, when compared to composite materials. The giomer-based bulk fill (GioBFe) resin promoted a reduction of $26 \%$ of enamel wear, which was similar to conventional glass ionomer (GICe), with a $27 \%$ reduction. The reference for calculating the enamel loss reduction was Z350 group, which was considered to promote $100 \%$ of enamel wear. This reduction was statistically significant until $200 \mu \mathrm{m}$ for GioBFe and on all distances for GICe. Therefore, the protective effect of adjacent enamel against erosion, promoted by giomer-based composite groups besides being restricted to enamel very close to the material, might not be ignored, because the gap between enamel and material can led to acids retention, increasing their deleterious effect.

Previous in vitro and in situ studies did not find difference on the prevention of enamel loss adjacent to different types of materials (amalgam, resin composite and glass ionomer cement) by means of perfilometry and hardness $[17,24]$. The explanation for the contradictory results, compared to the present study can be the profile measurement method, brand of the materials and the erosive protocol. On these studies, the profile reached around $1.5 \mathrm{~mm}$ distance from the material [17], probably diluting their potential protective effect, which was shown to be higher in the margins in our study. In addition, the present protocol consists of six erosive cycling during 5 days with citric acid against 3 erosive cycles with cola drink for 7 days [17, 24].

On the other hand, other studies also found less enamel loss adjacent to glass ionomer cements $[10,11]$. Rolim et al. 2012, evaluated the percentage of mineral loss on the surface around different restorations under the use of highly fluoridated dentifrices and the results showed that teeth restored with conventional GIC provided an additional protection against enamel erosion regardless of dentifrice used [10]. Similarly, Alghilan investigated the effect of erosion on restorative materials and on 
adjacent enamel, simulating different salivary flow rates, and found that fluoridecontaining materials promoted less loss of enamel surface under erosive challenges [11].

Although there is no agreement on the protective ability of the glass ionomer cement regarding adjacent enamel under erosive challenges [17, 25], the present study found the best effect for CGle. However, the modified glass ionomer resulted in similar enamel wear compared to Z350 group and it was expected a better performance. This result reinforces the knowledge that significant variation can exist among materials within a class, depending on factors such as the nature and size of the filler particles [9].

The protective effect found for giomer-based composite groups (Gioe and GioBFe) was similar to glass ionomer cement groups (GICe and RMGle). We hypothesize that fluoro-alumina-boro silicate glass filler can release Silicon, Strontium, Aluminum, Boron, Sodium, and Fluoride ions, neutralizing the erosive acids and reducing enamel demineralization [25]. Strontium presents a synergistic effect when applied in association with Fluoride, with an advantageous of replacing hydroxyl and calcium ions in the apatite structure [26].

When abrasion was conducted after erosion no protective effect was observed for the studied materials. Probably the ions released by the giomer-based composite groups and the fluoride by the glass ionomer cement groups did not promoted enamel mechanical resistance and the softened enamel was prone to loss due to abrasion. Even highly-concentrated polyvalent metal fluorides present limitation on the protective effect because the mechanical impact overcomes their chemical beneficial effect [27].

Regarding the material loss due to acid attack, the composite groups showed the lowest wear. This result is in accordance to previous studies $[9,28]$ and can be explained mainly by the low susceptibility of the composite matrix organic content [9, 29]. In the composite groups, we did not find statistic difference between wear conditions, since material wear of erosion alone was similar to erosion + abrasion. The mechanical resistance of the composite matrix in addition to bond stability between the filler and the matrix increases the abrasion resistance of the composite based restorative materials [29].

Glass ionomer cements showed the highest loss, which is in line with the literature $[9,27]$. Previous studies explain these results by the acid ability to dissolve the siliceous hydrogel layer, resulting in peripheral matrix dissolution and exposure the 
glass particles [23, 30, 31]. Since the dissolution of this matrix causes a softening of the material, it is easily removed by toothbrush abrasion as we can see on the present results (Table 1) and in the study conducted by Yu et al. [23].

The giomer-based composite groups showed similar wear compared to the composite groups. This result can be explained by the presence of bis-GMA and TEGDMA matrix, which is resistant to acid [16]. Contrary to the present study, Kooi et al. 2012, demonstrated that the Giomer's hardness and roughness are more affected than resin composites by citric acid, due to the fluorosilicate glass fillers greater susceptibility to degradation by weak acids [16]. For erosion+abrasion, giomer-based resin composites showed intermediate material wear compared to GIC (higher wear) and resin composite (less wear). Composites with small filler particles exhibit homogeneous and less prominent particles on the surface, which are less susceptible to removal by mechanical forces [16]. Probably fluorosilicate glass fillers are more superficial and prominent to promote ions release, but this characteristic might also facilitate their removal.

Given the limitations of this in vitro study, giomer-based resin composites have showed to be a potential alternative for the restorative treatment of patient with erosive tooth wear, due to their higher resistance to erosive and/or abrasive wear than glass ionomer cements, and their effective protection of enamel near to the restoration.

\section{Conclusion}

The null hypothesis was partial accepted. When the restoration was subjected to erosion, giomer-based resin composites, similar to resin composites, showed minor loss when compared to glass ionomer cement. In addition, promoted a reduction in enamel wear near the margin of restoration, which was also observed when conventional glass ionomer was used. None of the studied materials were able to protect enamel adjacent to restoration when erosion was associated to abrasion and this challenge resulted in intermediate loss of giomer-based composites compared to glass ionomer cement, which showed the highest wear, and resin composite with the lowest wear. 


\section{References}

[1] D. Bartlett. Tooth wear. Br Dent J. 224 (5) (2018) 283. doi: 10.1038/sj.bdj.2018.175.

[2] C. Tschammler, C. Müller-Pflanz, T. Attin, J. Müller, A. Wiegand. Prevalence and risk factors of erosive tooth wear in 3-6 year old German kindergarten children-A comparison between 2004/05 and 2014/15. J Dent. 52 (2016) 45-9. doi: 10.1016/j.jdent.2016.07.003.

[3] M.M. Salas, G.G. Nascimento, M.C. Huysmans, F.F, Demarco. Estimated prevalence of erosive tooth wear in permanent teeth of children and adolescents: an epidemiological systematic review and meta-regression analysis. J Dent. 43 (1) (2015) 42-50. doi: 10.1016/j.jdent.2014.10.012.

[4] C.D. Brusius, L.S. Alves, C. Susin, M. Maltz. Dental erosion among South Brazilian adolescents: A 2.5-year longitudinal study. Community Dent Oral Epidemiol. 46 (1) (2017) 17-23. doi: 10.1111/cdoe.12322.

[5] J.C. Carvalho, T. Scaramucci, N.R. Aimée, H.D. Mestrinho, A.T. Hara. Early diagnosis and daily practice management of erosive tooth wear lesions. Br Dent J. 224 (5) (2018) 311-318. doi: 10.1038/sj.bdj.2018.172.

[6] M.A.R. Buzalaf, A.C. Magalhães, D. Rios. Prevention of erosive tooth wear: targeting nutritional and patient-related risks factors. Br Dent J. 224 (5) (2018) 371378. doi: 10.1038/sj.bdj.2018.173.

[7] B. Loomans, N. Opdam. A guide to managing tooth wear: the Radboud philosophy. Br Dent J. 224 (5) 2018 348-356. doi: 10.1038/sj.bdj.2018.164.

[8] A. Peuzfeldt, T. Jaeggi, A. Lussi. Restorative therapy of erosive lesions. Monogr Oral Sci. 25 (2014) 253-261. doi: 10.1159/000360562.

[9] M. Shabanian, L.C. Richards. In vitro wear rates of materials under different loads and varying pH. J Prosthet Dent. 87 (6) (2002) 650-6.

[10] F.G. Rolim, A.F. Sá, G.W. Silva-Filho, Ade S. Brandim, G.C. Vale. Effect of HighFluoride Dentifrice on Enamel Erosion Adjacent to Restorations In Vitro. Oper Dent. 41 (2) (2016) 157-61. doi: 10.2341/14-292-L.

[11] M.A. Alghilan, N.B. Cook, J.A. Platt, G.J. Eckert, A.T. Hara. Susceptibility of restorations and adjacent enamel/dentine to erosion under different salivary flow conditions. J Dent. 43(12) (2015) 1476-82. doi: 10.1016/j.jdent.2015.10.007.

[12] Ikemura, K. et al. Optimizing fller content in an adhesive system containing prereacted glass-ionomer fllers. Dent Mater 19, 137-146 (2003). 
[13] Han L, Okiji T (2011) Evaluation of the ions release / incorporation of the prototype S-PRG filler-containing endodontic sealer. Dent Mater J 30:898-903

[14] Shimazu K, Ogata K, Karibe H (2011) Evaluation of the ionreleasing and recharging abilities of a resin-based fissure sealant containing S-PRG filler. Dent Mater J 30:923-927

[15] Kaga N, Toshima H, Nagano-Takebe F, Hashimoto M, Nezu T, Yokoyama A, Endo $\mathrm{K}$, Kaga M. Inhibition of enamel demineralization by an ion-releasing tooth-coating material. Am J Dent. 2019 Feb;32(1):27-30.

[16] T.J. Kooi, Q.Z. Tan, A. U. Yap, W. Guo, K.J. Tay, M.S. Soh. Effects of Foodsimulating Liquids on Surface Properties of Giomer Restoratives. Oper Dent. 37 (6) (2012) 665-671. doi: 10.2341/11-419-L.

[17] D. Rios, H.M. Honório, L.F. Francisconi, A.C. Magalhães, M.A. de Andrade Moreira Machado, M. A. Buzalaf. In situ effect of an erosive challenge on different restorative materials and on enamel adjacent to these materials. J Dent. 36 (2) (2008) 152-7. doi: 10.1016/j.jdent.2007.11.013.

[18] M.J. Tyras. Cariostatic effect of glass ionomer cement: a five-year clinical study. Australian Dental Journal 1991;36:236-9.

[19] L. Forsten. Clinical experience with glass ionomer for proximal fillings. Acta Odontol Scand. 51 (4) (1993) 195-200.

[20] H.M. Honório, D. Rios, L.F. Francisconi, A.C. Magalhães, M.A. Machado, M.A. Buzalaf. Effect of prolonged erosive $\mathrm{pH}$ cycling on different restorative materials. J Oral Rehabil. 35 (12) (2008) 947-53. doi: 10.1111/j.1365-2842.2008.01856.x.

[21] M. Yoneda, N. Suzuki, T. Hirofuji. Antibacterial Effect of Surface Pre-Reacted Glass Ionomer Filler and Eluate-Mini Review. Pharm Anal Acta. 6 (2015) 349. doi: 10.4172/2153-2435.1000349.

[22] J. Klimek, E. Hellwig, G. Ahrens. Effect of plaque on fluoride stability in the enamel after amine fluoride application in the artificial mouth. Dtsch Zahnarztl Z. 37(10) (1982) 836-40.

[23] H. Yu, F.J. Wegehaupt, A. Wiegand, M. Roos, T. Attin, W. Buchalla. Erosion and abrasion of tooth-colored restorative materials and human enamel. J Dent. 37 (12) (2009) 913-22. doi: 10.1016/j.jdent.2009.07.006.

[24] L.F. Francisconi, H.M. Honório, D. Rios, A.C. Magalhães, M.A.A.M. Machado, M.A.R. Buzalaf. Effect of Erosive $\mathrm{pH}$ cycling on Different Restorative Materials and on 
Enamel Restored with These Materials. Oper Dent. 33 (2) (2008) 203-8. doi: 10.2341/07-77.

[25] M. Kaga, S. Kakuda, Y. Ida, H. Toshima, M. Hashimoto, K. Endo, H. Sano. Inhibition of enamel demineralization by buffering effect of S-PRG fillercontaining dental sealant. Eur J Oral Sci. 122 (1) (2014) 78-83. doi: 10.1111/eos.12107.

[26] T.T. Thuy, H. Nakagaki, K. Kato, P.A. Hung, J. Inukai, S. Tsuboi, H. Nakagaki, M.N. Hirose, S. Igarashi, C. Robinson. Effect of strontium in combination with fluoride on enamel remineralization in vitro. Arch Oral Biol. 53 (11) (2008) 1017-22. doi: 10.1016/j.archoralbio.2008.06.005.

[27] M.C. Huysmans, A. Young, C. Ganss. The role of Fluoride in Erosion Therapy. Monogr Oral Sci. 25 (2014) 230-43. doi: 10.1159/000360555.

[28] M. Aliping-McKenzie, R.W. Linden, J.W. Nicholson. The effect of Coca-Cola and fruit juices on the surface hardness of glass-ionomers and 'compomers'. J Oral Rehabil. 31 (11) (2004) 1046-52.

[29] B. Zimmerli, M. Strub, F. Jeger, O. Stadler, A. Lussi.Composite materials: Composition, properties and clinical applications A Literature Review. Schweiz Monatsschr Zahnmed. 120(11) (2010) 972-86.

[30] W.A. El-Badrawy, D. McComb. Effect of home-use fluoride gels on resin-modified glass-ionomer cements. Oper Dent. 23 (1) (1998) 2-9.

[31] C.P. Turssi, A.T. Hara, M.C. Serra, A.L. Rodrigues Jr. Effect of storage media upon the surface micromorphology of resin-based restorative materials. J Oral Rehabil. 29 (9) (2002) 864-71. 


$$
\begin{aligned}
& z \\
& \frac{2}{5} \\
& \frac{1}{0}
\end{aligned}
$$





\section{DISCUSSION}

With the decrease in the prevalence of caries, there is a greater permanence of dental elements in mouth, and, associating this fact with an increase in the life expectancy, manifestations of erosive, abrasive and fatigue processes are more frequently observed (NUNN, 1996; ADDY; SHELLIS, 2006). It is believed that, clinically, these processes occur simultaneously, leading to a separation between the concepts "dental erosion" and "erosive tooth wear" (SHELLIS et. al., 2011; HUYSMANS; CHEW; ELLWOOD, 2011).

The term erosion is used to name the process of loss of structural integrity and mechanical resistance caused by the effect of acids of intrinsic and extrinsic origin, without involving microorganisms, on the surface of the tooth, corresponding only to a superficial softening without loss of structure in height (LUSSI; JAEGG; ZERO, 2004; LUSSI; HELLWIG, 2006; SHELLIS et. al., 2011; HUYSMANS; CHEW; ELLWOOD, 2011). On the other hand, dental wear refers to a great loss of dental structure, caused by the initial softening and subsequent removal of this soft tissue through abrasive actions (SHELLIS et. al., 2011; HUYSMANS; CHEW; ELLWOOD, 2011), being the process we can see clinically. Due to this increase, several studies have been directed to erosive dental wear, in order to prevent its formation or to contain its progression (AMAECHI; HIGHAM, 2005). However, it is observed a difficulty in interfering with the patient habits (LUSSI, 2006; SERRA; MESSIAS; TURSSI, 2009), leading to the progression of lesions and consequent need for restorative therapies (LUSSI 2005; LUSSI; CARVALHO, 2014; ZERO), objectifying to reduce symptomatic, functional and aesthetic problems (PEUZFELDT; JAEGGI; LUSSI, 2014).

Within the necessity of restoring these lesions, the purpose of this study was to test and evaluate the giomer-based composites under erosive wear and their ability to protect the adjacent enamel compared to composites and ionomers.

The present study followed an in vitro methodology, since it is an initial study on this subject, requiring a shorter period of time, low operational cost and not dependent on the volunteers' collaboration. 
About the material itself, the results showed that there was less wear on the composite groups; this lower susceptibility is due to their three basic components: composite matrix (organic content - Bis-GMA / TEGDMA - responsible for the slight softening of the material), fillers (inorganic part) and coupling agents (NISHIO; YAMAMOTO, 2002; YONEDA et. al., 2012). In the composite groups, there was no statistic difference between conditions, since the values of wear on erosion alone were similar to erosion + abrasion; because the stable bond between the filler and the matrix increases the abrasion resistance of the restorative material (YONEDA et. al., 2012).

The glass ionomer cements showed the highest loss. Previous studies explain these results by the dissolution of the peripheral matrix to their glass particles, which could result from dissolution of the siliceous hydrogel layer (TOKUNAGA et. al., 2013; GORDAN et. al. 2014; SUZUKI et. al., 2015). Since the dissolution of this matrix and this degraded layer cause a softening of the material, being easily removed by toothbrush abrasion as we can see on the study conducted by Hao Yu et. al. (2009), explaining the significant difference found between conditions.

The Giomer group is a hybrid composite restorative material, also known as "pre-reacted glass ionomer"(S-PRG), it contains fluoro-alumina-silicate glass, which reacts with polyalkenoic acid in water before being incorporated into a silica-filled urethane resin, presenting the fluoride release and recharge properties of glassionomer (ZIMMERLI et. al. 2010), Kooi et. al. (2012) demonstrated that the Giomer's hardness and roughness are more affected than in resin composite, being significantly degraded by citric acid, attributed to the greater susceptibility of fluorosilicate glass fillers to degradation by weak acids (KOOI et. al., 2012). Apart from that, composites with small filler particles are more wear resistant, with further homogeneous and less prominent particles on the surface (KOOI et. al., 2012), still the giomer composites are significantly higher than the resin composites, which could explain it higher susceptibility for erosion + abrasion than the composites; however, this wear was still lower than the ionomer groups. A study conducted by Walia et. al. (2016) comparing the compressive strength of various materials showed that the resin-based PRG fillers and cross-linked polymer matrices result in the higher compressive strength than the acid-base reaction in glass ionomers. 
The type of acid chosen can also influence on the amount of wear. In this study the citric acid ( $\mathrm{pH} 2.5$ ) was chosen for simulating vegetables, fruits, candies, syrups and certain beverages [17], yet Guedes et. al. (2018) showed that the hydrochloric acidic solution ( $\mathrm{pH} 2.0)$ caused largest changes in surface roughness and micro hardness of restorative materials when compared with the Soft drink $(\mathrm{pH} 3.6)$, confirming that the gastric juice has a more severe erosion potential, which could produce a greater wear in the present study.

According to the current literature, enamel present higher wear when compared to restorative materials (EL-BADRAWY; MCCOMB, 1998; NISHIO; YAMAMOTO, 2002). In caries, there is a capacity of protection on the adjacent enamel by ionomer restorations and Giomer-based composites (TYRAS, 1991; FORSTEN, 1993; TURSSI et. al., 2002; WONGKHANTEE et. al., 2006; RIOS et. al., 2007; YU et. al., 2009; ALGHILAN et. al., 2015; GONULOL; OZER; SEN TUNC, 2015; WALIA et. al., 2016; ALBUQUERQUE GUEDES et. al., 2018). However, there is no agreement on the protective ability of the ionomer in the adjacent enamel under erosive challenges. In the present study, a significant lower wear was found on the enamel adjacent of the glass ionomer and giomer restorations up to $300 \mu \mathrm{m}$ under erosion condition.

Different from Rios et. al. (2008), that tested the in situ effect of erosion on the amalgam, resin composite and glass ionomer cement and on the enamel adjacent to them likewise Francisconi et. al. (2008) in an in vitro study, also testing these materials, by means of perfilometry and percentage of hardness loss and as a result did not observe significant difference between the groups, presenting a minimal alteration on micro hardness and similar alteration on perfilometry, that could be explained by the quantity of erosive challenge, which were submitted three times a day for seven days and in this study was performed six times a day for five days; besides the type of beverage they used, Cola drink, that shows lesser reduction in surface hardness compared to citric acid (ALIPING-MCKENZIE; LINDEN; NICHOLSON, 2004).

On the other hand a study conducted by Rolim et. al. (2016) in order to evaluate the percentage of mineral loss on the surface around different restorations under the use of highly fluoridated dentifrices, using also the Cola drink, but submitting the specimens for four erosive challenges per day for five days and showed that the use of a high-F dentifrice on teeth restored with conventional GIC provided an additional 
protection against enamel erosion. Similarly, Alghilan et. al. (2015) investigated the effect of erosion on restorative materials and enamel adjacent to them, considering different salivary fluxes, simulating a greater exposure to risk factors, they used citric acid and also submitted the specimens for four erosive challenges per day for five days and found that fluorine-containing materials presented less loss of surface under acidic challenges. An explanation for the observed erosion protection around fluoridecontaining restorations is about the highly erosive conditions. Since the difference between materials was only observed when up to four challenges per day, like in the present study.

The protective effect of Giomer-based composites on the adjacent enamel is statistic similar to glass ionomer cements. This can be explained by the modest quantities of Silicon, Strontium, Aluminum, Boron, Sodium, and Fluoride ions, involved in neutralizing and subsequent reducing the enamel demineralization (KAGA et. al., 2014). Attention should be given to the capacity of Strontium to enhance remineralization, with a synergistic effect when applied in conjunction with Fluoride, with an advantageous of replacing hydroxyl and calcium ions in the apatite structure (THUY et. al. 2008).

The fluoride release of glass ionomer cements and the giomer-based composites didn't show a protective effect on erosion + abrasion condition on enamel. That is because in erosion the demineralization is limited to the surface, but when the erosive challenge continues, usually added to the abrasion, the softened tooth surface is easily lost, leaving a little time and opportunity for the fluoride act on the remineralization (MAGALHÃES et. al. 2011), as long as the protective effect of fluoride on demineralization is seen when using high-concentration or with polyvalent metal fluorides, but both offer a short-living protection, not enough for a high erosive plus abrasive challenge like in the present study (HUYSMANS; YOUNG; GANSS, 2014).

Considering the distance of protective effect from glass ionomer and giomer, we can see a restricted protection of the enamel up to $300 \mu \mathrm{m}$ of distance to the material, which implies clinically in a smaller formation of micro leakage, reducing biofilm retention as well as the action of future acids. 
2
0
5
3
0
0 



\section{CONCLUSION}

Given the limitations of this in vitro study, giomer-based composites have showed to be a potential alternative for the restorative treatment of patient with erosive tooth wear, due to their higher resistance to erosive and/or abrasive wear than glass ionomer cements, and their effective protection of enamel loss near to the restoration. 

岂 



\section{REFERENCES}

Addy M, Shellis RP. Interaction between attrition,abrasion and erosion in tooth wear. Monogr Oral Sci. 2006;20:17-31.

Akimoto N, Ohmori K, Hanabusa M, Momoi Y. An eighteen-month clinical evaluation of posterior restorations with fluoride releasing adhesive and composite systems. Dent Mater J. 2011;30(3):411-8.

Albuquerque Guedes AP, Oliveira-Reis B, Catelan A, Umeda Suzuki TY, Fraga Briso $\mathrm{AL}$, Dos Santos $\mathrm{PH}$. Mechanical and surface properties analysis of restorative materials submitted to erosive challenges in situ. Eur J Dent. 2018;12(4):559-565.

Alghilan MA, Cook NB, Platt JA, Eckert GJ, Hara AT. Susceptibility of restorations and adjacent enamel/dentine to erosion under different salivary flow conditions. J Dent. 2015;43(12):1476-82.

Aliping-McKenzie M, Linden RW, Nicholson JW. The effect of Coca-Cola and fruit juices on the surface hardness of glass-ionomers and 'compomers'. J Oral Rehabil. 2004;31(11):1046-52.

Amaechi BT, Higham SM. Dental erosion: possible approaches to prevention and control. J Dent. 2005;33(3):243-52.

Attin T, Buchalla W, Gollner M, Hellwig E. Use of variable remineralization periods to improve the abrasion resistance of previously eroded enamel. Caries Res 2000;34:4852.

Brusius CD, Alves LS, Susin C, Maltz M. Dental erosion among South Brazilian adolescents: A 2.5-year longitudinal study. Community Dent Oral Epidemiol. 2018;46(1):17-23.

Carvalho TS, Colon P, Ganss C, Huysmans MC, Lussi A, Schlueter N, Schmalz G, Shellis RP, Tveit AB, Wiegand A. Consensus report of the European Federation of Conservative Dentistry: erosive tooth wear--diagnosis and management. Clin Oral Investig. 2015 Sep;19(7):1557-61.

El-Badrawy WA, McComb D. Effect of home-use fluoride gels on resin-modified glassionomer cements. Oper Dent. 1998;23(1):2-9. 
Forsten L. Clinical experience with glass ionomer for proximal fillings. Acta Odontol Scand. 1993;51(4):195-200.

Francisconi LF, Honório HM, Rios D, Magalhães AC, Machado MAAM, Buzalaf MAR. Effect of Erosive pH Cycling on Different Restorative Materials and on Enamel Restored with These Materials. Oper Dent. 2008;33(2):203-208.

Gonulol N, Ozer S, Sen Tunc E. Water sorption, solubility, and color stability of giomer restoratives. J Esthet Restor Dent. 2015;27(5):300-6.

Gordan VV, Blaser PK, Watson RE, Mjör IA, McEdward DL, Sensi LG, Riley JL 3rd. A clinical evaluation of a giomer restorative system containing surface prereacted glass ionomer filler: results from a 13-year recall examination. $J$ Am Dent Assoc. 2014;145(10):1036-43.

Grippo JO, Simring M, Schreiner S. Attrition, abrasion, corrosion and abfraction revisited: a new perspective on tooth surface lesions. J Am Dent Assoc. 2004;135(8):1109-18.

Hellwi E, Lussi A. Oral hygiene products, medications and drugs - hidden aetiological factors for dental erosion. Monogr Oral Sci. 2014;25:155-62.

Honório HM, Rios D, Francisconi LF, Magalhães AC, Machado MA, Buzalaf MA. Effect of prolonged erosive $\mathrm{pH}$ cycling on different restorative materials. J Oral Rehabil. 2008;35(12):947-53.

Huysmans MC, Chew HP, Ellwood RP. Clinical studies of dental erosion and erosive wear. Caries Res. 2011;45(1):60-8.

Huysmans MC, Young A, Ganss C. The role of Fluoride in Erosion Therapy. Monogr Oral Sci. 2014;25:230-43.

Kaga M, Kakuda S, Ida Y, Toshima H, Hashimoto M, Endo K, Sano H. Inhibition of enamel demineralization by buffering effect of S-PRG filler-containing dental sealant. Eur J Oral Sci. 2014;122(1):78-83.

Kawasaki K, Kambara M. Effects of ion-releasing tooth-coating material on demineralization of bovine tooth enamel. Int J of Dent. 2014;463149:1-7.

Kooi TJM, Tan QZ, Yap AUJ, Guo W, Tay KJ, Soh MS. Effects of Food-simulating Liquids on Surface Properties of Giomer Restoratives. Oper Dent. 2012;37(6):665-671. 
Kurokawa H, Takamizawa T, Rikuta A, Tsubota K, Miyazaki M. Three-year clinical evaluation of posterior composite restorations placed with a single-step self-etch adhesive. J Oral Sci. 2015;57(2):101-8.

Lussi A, Carvalho TS. Erosive Tooth Wear: A multifactor condition of growing concern and increasing Knowledge. Monogr Oral Sci. 2014;25:1-15.

Lussi A, Hellwig E. Risk assessment and preventive measures. Monogr Oral Sci. 2006;20:190-9.

Lussi A, Jaeggi T, Zero D. The role of diet in the aetiology of dental erosion. Caries Res. 2004;38(1):34-44.

Lussi A. Erosive tooth wear - a multifactorial condition of growing concern and increasing knowledge. Monogr Oral Sci. 2006;20:1-8.

Magalhães AC, Wiegand A, Rios D, Buzalaf MA, Lussi A. Fluoride in dental erosion. Monogr Oral Sci. 2011;22:158-70.

Nakamura N, Yamada A, Iwamoto T, Arakaki M, Tanaka K, Aizawa S, Nonaka K, Fukumoto S. Two-year clinical evaluation of flowable composite resin containing prereacted glass-ionomer. Pediatr Dent J. 2009;19(1):89-97.

Nishio $\mathrm{M}$, Yamamoto $\mathrm{K}$. The anti-dental plaque effect of fluoride releasing light-cured composite resin restorative material. Jpn J Conserv Dent. 2002;45(3):459-468.

Nunn JH, Gordon PH, Morris AJ, Pine CM, Walker A. Dental erosion -- changing prevalence? A review of British National childrens' surveys. Int J Paediatr Dent. 2003;13(2):98-105.

Nunn JH. Prevalence of dental erosion and the implications for oral health. Eur $\mathrm{J}$ Oral Sci 1996;104:156-161.

Peuzfeldt A, Jaeggi T, Lussi A. Restorative Therapy of Erosive Lesions. Monogr Oral Sci. 2014;25: 253-261.

Rios D, Honório HM, Francisconi LF, Magalhães AC, de Andrade Moreira Machado MA, Buzalaf MA. In situ effect of an erosive challenge on different restorative materials and on enamel adjacent to these materials. J Dent. 2008;36(2):152-7. 
Rolim FG, Sá AF, Silva-Filho GW, Brandim Ade S, Vale GC. Effect of High-Fluoride Dentifrice on Enamel Erosion Adjacent to Restorations In Vitro. Oper Dent. 2016;41(2):157-61.

Salas MM, Nascimento GG, Huysmans MC, Demarco FF. Estimated prevalence of erosive tooth wear in permanent teeth of children and adolescents: an epidemiological systematic review and meta-regression analysis. J Dent. 2015;43(1):42-50.

Serra MC, Messias DC, Turssi CP. Control of erosive tooth wear: possibilities and rationale. Braz Oral Res. 2009;23(1):49-55.

Shellis RP, Ganss C, Ren Y, Zero DT, Lussi A. Methodology and models in erosion research: discussion and conclusions. Caries Res. 2011;45(1):69-77.

Shiiya T, Mukai Y, Tomiyama K, Teranaka T. Anti-demineralization effect of a novel fluoride-releasing varnish on dentin. Am J Dent. 2012;25(6):347-50.

Shimazu K, Ogata K, Karibe H. Caries-preventive effect of fissure sealant containing surface reaction-type pre-reacted glass ionomer filler and bonded by self-etching primer. J Clin Pediatr Dent. 2012;36(4):343-7.

Shirai T, Arai Y, Nagai K, Takagi R. Caries-Preventive Effect of Mouthguards Containing S-PRG Filler. Japan Acad of Sports Dent. 2015;19(1):8-13.

Suzuki M, Yamada A, Saito K, Hino R, Sugawara Y, Ono M, Naruse M, Arakaki M, Fukumoto S. Application of a tooth-surface coating material containing pre-reacted glass-ionomer fillers for caries prevention. Pediatr Dent J. 2015;25(3):72-78.

Ten Cate JM, Imfeld T. Dental erosions summary. Eur J Oral Sci. 1996;104 (2 Pt 2):241-4.

Thuy TT, Nakagaki H, Kato K, Hung PA, Inukai J, S. Tsuboi S, Nakagaki SH, Hirose $\mathrm{MN}$, Igarashi S, Robinson C. Effect of strontium in combination with fluoride on enamel remineralization in vitro. Arch Oral Biol. 2008;53(11):1017-22.

Tokunaga Y, Nakano T, Kato K, Fukuta O. Fluoride Release and Recharge Capabilities of Orthodontic Resin Containing S-PRG Filler. Shoni Shikagaku Zasshi. 2013;51(1):1-7.

Tschammler C, Müller-Pflanz C, Attin T, Müller J, Wiegand A. Prevalence and risk factors of erosive tooth wear in 3-6 year old German kindergarten children-A comparison between 2004/05 and 2014/15. J Dent. 2016;52:45-9. 
Turssi CP, Hara AT, Serra MC, Rodrigues Jr AL. Effect of storage media upon the surface micromorphology of resin-based restorative materials. J Oral Rehabil. 2002;29 (9):864-71.

Tyras MJ. Cariostatic effect of glass ionomer cement: a five-year clinical study. Aust Dent J 1991;36:236-9.

Walia R, Jasuja P, Verma KG, Juneja S, Mathur A, Ahuja L. A comparative evaluation of microleakage and compressive strength of Ketac Molar, Giomer, Zirconomer, and Ceram-X: An in vitro study. J Indian Soc Pedod Prev Dent. 2016;34(3):280-4.

Wongkhantee S, Patanapiradej V, Maneenut C, Tantbirojn D. Effect of acidic food and drinks on surface hardness of enamel, dentine, and tooth-colored filling materials. J Dent. 2006;34(3):214-20.

Yoneda M, Suzuki N, Hirofuji T. Antibacterial Effect of Surface Pre-Reacted Glass Ionomer Filler and Eluate-Mini Review. Pharm Anal Acta 2015;6:349.

Yoneda M, Suzuki N, Masuo Y, Fujimoto A, Iha K, Yamada K, Iwamoto T, Hirofuji T. Effect of S-PRG Eluate on Biofilm Formation and Enzyme Activity of Oral Bacteria. Int J Dent. 2012;2012:814913.

Yu H, Wegehaupt FJ, Wiegand A, Roos M, Attin T, Buchalla W. Erosion and abrasion of tooth-colored restorative materials and human enamel. J Dent. 2009;37(12):913-22.

Zero DT, Lussi A. Erosion - chemical and biological factors of importance to the dental practitioner. Int Dent J 2005;55:285-290.

Zimmerli B, Strub M, Jeger F, Stadler O, Lussi A. Composite materials: Composition, properties and clinical applications A Literature Review. Schweiz Monatsschr Zahnmed. 2010;120(11):972-86. 